AGRITECH, Vol. 37, No. 2, Mei 2017, Hal. 148-157 DOI: http://doi.org/10.22146/agritech.10397 ISSN 0216-0455 (Print), ISSN 2527-3825 (Online)

Tersedia online di https://jurnal.ugm.ac.id/agritech/

\title{
Ekstraksi Komponen Bioaktif Daun Alpukat dengan Bantuan Ultrasonik pada Berbagai Jenis dan Konsentrasi Pelarut
}

\section{Extraction of Bioactive Compounds from Avocado Leaves by Sonication at Various Solvent Types and Concentration}

\author{
I Wayan Rai Widarta' ${ }^{1}$ I Wayan Arnata² \\ ${ }^{1} J u r u s a n$ Ilmu dan Teknologi Pangan, Fakultas Teknologi Pertanian, Universitas Udayana, \\ Kampus Bukit Jimbaran, Badung 80364, Indonesia \\ ${ }^{2}$ Jurusan Teknologi Industri Pertanian, Fakultas Teknologi Pertanian, Universitas Udayana, \\ Kampus Bukit Jimbaran, Badung 80364, Indonesia \\ Email: rai_widarta@yahoo.com
}

Submisi: 24 Februari 2016; Penerimaan: 9 Agustus 2016

\begin{abstract}
ABSTRAK
Daun alpukat mengandung komponen bioaktif yang tinggi sehingga dapat dimanfaatkan sebagai sumber antioksidan. Tujuan penelitian ini adalah mendapatkan jenis dan konsentrasi pelarut yang tepat untuk menghasilkan komponen bioaktif dan aktivitas antioksidan yang tinggi dari ekstrak daun alpukat. Penelitian dilakukan dalam dua tahapan. Pada tahap I dilakukan penentuan jenis dan konsentrasi pelarut untuk menghasilkan ekstrak daun alpukat dengan aktivitas antioksidan tertinggi. Rancangan yang digunakan adalah rancangan acak lengkap pola faktorial dengan faktor I adalah jenis pelarut (metanol, etanol dan aseton) dan faktor II adalah konsentrasi pelarut (30\%, 50\%, dan 70\%). Pada tahap II dilakukan penentuan $\mathrm{IC}_{50}$ dari ekstrak daun alpukat yang memiliki aktivitas antioksidan tertinggi. Hasil penelitian menunjukkan bahwa pelarut yang tepat digunakan untuk memperoleh ekstrak daun alpukat dengan aktivitas antoksidan yang tertinggi adalah etanol $70 \%$ dengan kadar total fenolik, flavonoid, tanin, dan aktivitas penghambatan radikal DPPH masing-masing adalah $23,28 \mathrm{mg} / \mathrm{g}$ bahan, $93,97 \mathrm{mg} / \mathrm{g}$ bahan, $9,47 \mathrm{mg} / \mathrm{g}$ bahan, dan $90,80 \%$. Sementara itu, nilai $\mathrm{IC}_{50}$ baik yang diukur dengan metode $\mathrm{DPPH}$, pengkelatan $\mathrm{Fe}^{2+}$ maupun reducing power masing-masing adalah 1870 $\mathrm{mg} / \mathrm{L}, 1180 \mathrm{mg} / \mathrm{L}$, dan $85,24 \mathrm{mg} / \mathrm{L}$.
\end{abstract}

Kata kunci: Antioksidan; daun alpukat; ekstraksi; pelarut

\begin{abstract}
ABTRACT
Avocado leaves contain high bioactive components that can be utilised as a source of antioxidants. The purpose of this research was to obtain the appropriate solvent types and concentration to recover high level of bioactive compounds and high antioxidant activity from the avocado leaves' extract. This study was conducted in two stages. The first stage was the determination of the solvent types and concentration in producing the extract of avocado leaves with the highest antioxidant activity. The research was designed using complete randomised factorial design with the type of solvent (methanol, ethanol, acetone) as the first factor and the second factor was the solvent concentration (30\%, 50\%, $70 \%$ ). The second stage of this research was the IC50 determination of avocado leaves which has highest antioxidant activity. The result showed that the appropriate solvent used in obtaining the extract of avocado leaves with the highest antioxidant activity was $70 \%$ ethanol. The total contents of phenolic, flavonoids, tannins, and DPPH radical inhibition activity of this extract were $23.28 \mathrm{mg} / \mathrm{g}$ materials, $93.97 \mathrm{mg} / \mathrm{g}$ materials, $9.47 \mathrm{mg} / \mathrm{g}$ materials and $90.80 \%$, respectively. Whereas, $\mathrm{IC}_{50}$ value measured using DPPH, $\mathrm{Fe}^{2+}$ chelating, and reducing power were $1870 \mathrm{mg} / \mathrm{L}, 1180 \mathrm{mg} / \mathrm{L}$ and 85.24 $\mathrm{mg} / \mathrm{L}$, respectively.
\end{abstract}

Keywords: Antioxidant; avocado leaves; extraction, solvent 


\section{PENDAHULUAN}

Tanaman alpukat merupakan salah satu tanaman yang tumbuh di daerah beriklim tropis dan sub tropis sehingga sangat mudah tumbuh di Indonesia. Bagian tanaman alpukat yang banyak dimanfaatkan adalah buahnya sebagai makanan segar dan sebagai bahan dasar kosmetik. Bagian lain yang dapat dimanfaatkan adalah daunnya yang muda sebagai obat tradisional. Menurut Asaolu dkk. (2010), daun alpukat merupakan salah satu sumber antioksidan. Menurut Arukwe dkk. (2012) daun alpukat mengandung beberapa komponen bioaktif seperti senyawa-senyawa fenolik. Hasil penelitian menunjukkan bahwa daun alpukat dapat membantu dalam mencegah atau memperlambat kemajuan berbagai stres oksidatif (Owolabi dkk., 2010), ekstrak daun alpukat dapat digunakan sebagai antibakteri (Ogundare dan Oladejo, 2014), antihipertensi (Tahla dkk., 2011), obat hiperlipidemia (Kolawole dkk., 2012), dan antidiabetes (Marrero-Faz dkk., 2014). Selain itu, Mardiyaningsih dan Ismiyati (2014) menyatakan bahwa ekstrak daun alpukat dapat menghambat pertumbuhan sel kanker leher rahim HeLa. Kultur sel HeLa atau HeLa cell line merupakan continuous cell line yang diturunkan dari sel epitel kanker leher rahim (cervix) seorang wanita penderita kanker leher rahim bernama Henrietta Lacks yang meninggal akibat kanker pada tahun 1951. Kultur sel ini memiliki sifat semi melekat dan digunakan sebagai model sel kanker dan untuk mempelajari sinyal transduksi seluler. Sel HeLa ini cukup aman dan merupakan sel manusia yang umum digunakan untuk kepentingan kultur sel.

Komponen bioaktif pada daun alpukat dapat diperoleh melalui proses ekstraksi. Ekstraksi dapat dilakukan dengan berbagai cara, salah satunya adalah dengan bantuan ultrasonik. Metode ekstraksi dengan bantuan ultrasonik direkomendasikan sebagai salah satu teknik ekstraksi konvensional karena biayanya murah, sederhana dan efisien (Bimakr dkk., 2013). Menurut Ince dkk. (2013), rendemen total fenolik yang diperoleh dari ekstraksi menggunakan ultrasonik lebih besar dibandingkan metode maserasi serta waktu yang dibutuhkan juga lebih singkat. Dimana, ekstraksi menggunakan metode maserasi membutuhkan waktu 24 jam sedangkan ekstraksi dengan menggunakan ultrasonik hanya membutuhkan waktu 20 menit. Efisiensi ekstraksi dipengaruhi oleh berbagai faktor seperti suhu dan waktu ekstraksi, jenis dan konsentrasi pelarut, rasio bahan dengan pelarut, serta ukuran partikel (Chew dkk., 2011. Lebih lanjut dikatakan bahwa jenis pelarut merupakan yang paling penting dalam mempengaruhi efisiensi ekstraksi. Hal ini disebabkan oleh polaritas komponen antioksidan yang berbeda (Fatiha dkk., 2012). Kelarutan suatu zat ke dalam suatu pelarut sangat ditentukan oleh kecocokan sifat atau struktur kimia antara zat terlarut dengan pelarut, yaitu like disolves like (Hismath dkk., 2011). Berbagai konsentrasi pelarut yang digunakan menunjukkan perbedaan pengaruh akibat perubahan polaritas sehingga mempengaruhi kelarutan flavonoid (Zhang dkk., 2009). Oleh karena itu, penentuan jenis dan konsentrasi pelarut yang tepat dalam proses ekstraksi diperlukan untuk mengoptimalkan perolehan kadar komponen bioaktif dan aktivitas antioksidan daun alpukat.

\section{METODE PENELITIAN}

\section{Bahan dan Alat}

Bahan-bahan yang digunakan adalah daun alpukat muda (warna hijau muda). Daun alpukat diperoleh dengan memetik langsung daun alpukat, dimana pohonnya berada di daerah Denpasar, Bali. Kemudian dicuci bersih, ditiriskan, selanjutnya langsung dikeringkan dengan oven (tidak ada penyimpanan). Setelah kering langsung digiling, dan diayak kemudian diekstraksi. DPPH (SigmaAldrich), reagen Folin-Ciocalteu (Merck), etanol (Merck), akuades, metanol (Merck), aseton $\mathrm{NaOH}$ (Merck), sodium karbonat (Merck), standar asam tanat (Sigma Aldrich), reagen Follin Denis (Merck), standar asam galat (Sigma Aldrich), buffer posfat, $\mathrm{NaNO}_{2}$ (Merck), $\mathrm{AlCl}_{3}$ (Merk), potasium ferisianida (Merck), trichloroacetic acid (Merck), $\mathrm{FeCl}_{3}$ (Merck), dan standar kuersetin (Sigma Aldrich). Alat-alat yang dipergunakan dalam penelitian ini adalah sonicator (Elma $\mathrm{S} 450 \mathrm{H})$, oven, spektrofotometer (Genesys 10S UV-Vis), rotary evaporator vakum IKA RV 10 basic), timbangan analitik (Shimadzu ATY224), Waterbath (J.P. Selecta, s.a) kertas Whatman No. 1 , dan alat-alat gelas.

\section{Persiapan Sampel}

Daun alpukat muda dikeringkan dengan menggunakan oven pada suhu $40{ }^{\circ} \mathrm{C}$ selama 24 jam hingga kadar air $\leq$ $10 \%$. Selanjutnya daun alpukat kering dihaluskan dengan menggunakan blender kemudian diayak dengan ayakan 60 mesh. Sampel siap digunakan untuk proses ekstraksi.

\section{Ekstraksi Daun Alpukat}

Sebanyak $15 \mathrm{~g}$ daun alpukat dilarutkan dengan 150 $\mathrm{mL}$ pelarut metanol, etanol, dan aseton (sesuai perlakuan) dengan konsentrasi sesuai perlakuan $(30 \%, 50 \%$, dan $70 \%)$. Perbandingan bahan dengan pelarut adalah 1:10 (b/v) kemudian di tempatkan dalam sonikator selama 40 menit pada suhu kamar dengan frekuensi $37 \mathrm{kHz}$. Selanjutnya disaring dengan kertas saring whatman no 1. Filtrat yang diperoleh dipekatkan dalam rotari evaporator vakum pada suhu 30 ${ }^{\circ} \mathrm{C}$ sehingga diperoleh ekstrak kasar daun alpukat. Ekstrak kasar yang diperoleh selanjutnya dianalisis: kadar total flavonoid, total tannin, total fenolik, dan aktivitas antioksidan 
(penghambatan radikal DPPH). Indikator hasil penelitian terbaik pada tahap ini adalah ekstrak yang memiliki aktivitas antioksidan tertinggi. Hasil terbaik pada tahap I selanjutnya diuji aktivitas antioksidannya melalui beberapa metode yaitu, penentuan nilai $\mathrm{IC}_{50}$ dengan metode $\mathrm{DPPH}$, pengkelatan ion $\mathrm{Fe}^{2+}$, dan reducing power.

\section{Penentuan Total Fenolik}

Penentuan total fenolik dengan metode Folin-Ciocalteau (Garcia dkk., 2007). Reagen Folin-Ciocalteu didilusi dengan air 1:9 (v/v). Kedalam 1,25 $\mathrm{mL}$ reagen ini ditambahkan 50 $\mu \mathrm{L}$ sampel. Setelah itu, diinkubasi selama 2 menit pada suhu ruang, kemudian ditambahkan $1 \mathrm{~mL}$ sodium karbonat (75 $\mathrm{g} / \mathrm{L}$ ). Selanjutnya diinkubasi selama 15 menit pada suhu 50 ${ }^{\circ} \mathrm{C}$ dan didinginkan dengan cepat dalam wadah yang berisi air es. Absorbansi dibaca pada panjang gelombang $760 \mathrm{~nm}$ dalam 15 menit. Hasil pembacaan dibandingkan dengan kurva standar menggunakan asam galat.

\section{Penentuan Total Flavonoid}

Penentuan total flavonoid dilakukan dengan metode Singh dkk. (2012). Sebanyak $1 \mathrm{~mL}$ sampel dicampur dengan $4 \mathrm{~mL}$ akuades dan $0,3 \mathrm{~mL}$ larutan $\mathrm{NaNO}_{2}(10 \%)$. Setelah 5 menit, ditambahkan $0,3 \mathrm{~mL}$ larutan $\mathrm{AlCl}_{3}(10 \%)$, diikuti oleh $2 \mathrm{~mL}$ larutan $\mathrm{NaOH}$ (1\%), lalu langsung diuji dengan spektrofotometer. Absorbansi campuran diukur pada panjang gelombang $510 \mathrm{~nm}$. Kurva standar kuersetin disiapkan (0-12 $\mathrm{mg} / \mathrm{mL}$ ). Konsentrasi flavonoid dalam sampel uji dihitung dari standar kalibrasi dan dinyatakan sebagai ekuivalen kuersetin dalam $\mathrm{mg} / \mathrm{g}$ sampel.

\section{Penentuan Total Tanin}

Penentuan total tanin sesuai dengan yang dilakukan oleh Rajan dkk. (2011). Ekstrak sebanyak 0,1 mL dicampurkan dengan $0,5 \mathrm{~mL}$ reagen folin Denis dan $1 \mathrm{~mL}$ larutan $\mathrm{Na}_{2} \mathrm{CO}_{3}$ $(0,5 \% \mathrm{~b} / \mathrm{v})$ dan diencerkan hingga volumenya $10 \mathrm{~mL}$ dengan menggunakan akuades. Absorbansi diukur pada panjang gelombang $755 \mathrm{~nm}$ dalam 30 menit. Total tanin pada ekstrak diekspresikan sebagai ekuivalen terhadap asam tanat.

\section{Penentuan Aktivitas Penghambatan Radikal DPPH dan $\mathrm{IC}_{\mathbf{5 0}}$}

Penentuan aktivitas antioksidan dan $\mathrm{IC}_{50}$ dengan metode DPPH sesuai dengan yang dilakukan oleh Khan dkk. (2012). Sebanyak $3 \mathrm{~mL}$ DPPH $(0,004 \%$ b/v dalam metanol $)$ dilarutkan dengan $100 \mu \mathrm{L}$ ekstrak daun alpukat (konsentrasi 1\%) dalam tabung reaksi. Larutan dishaker dan diinkubasi selama 30 menit dalam gelap dan suhu ruang. Absorbansi dibaca pada panjang gelombang $517 \mathrm{~nm}$ terhadap kontrol (sebagai 100\%) menggunakan spektrofotometer. Metanol digunakan sebagai blanko. Persentase kemampuan menangkap radikal bebas (aktivitas antioksidan) dihitung dengan rumus:

Aktivitas antioksidan $(\%)=\frac{\text { Absorbansikontrol }- \text { absorbansisampel }}{\text { Absorbansikontrol }} \times 100$

Absorbansi kontrol adalah absorbansi DPPH ditambahkan dengan metanol. Absorbansi sampel adalah absorbansi DPPH dengan ekstrak. Selanjutnya hasil perhitungan dimasukkan ke dalam persamaan regresi $\mathrm{Y}=$ $\mathrm{aX}+\mathrm{b}$. Konsentrasi ekstrak (100-2000 mg/L) sebagai absis (sumbu X) dan nilai \% inhibisi (aktivitas antioksidan) sebagai ordinatnya (sumbu Y). Nilai $\mathrm{IC}_{50}$ dari perhitungan pada saat $\%$ inhibisi sebesar $50 \%$.

\section{Penentuan Aktivitas Antioksidan dengan Pengkelatan Ion $\mathrm{Fe}^{2+}$}

Penentuan aktivitas pengkelatan ion $\mathrm{Fe}^{2+}$ sesuai yang dilakukan oleh Khan dkk. (2012). Ekstrak sebanyak 2.5 $\mathrm{mL}$ (konsentrasi ekstrak 0-2mg/ml) ditambahkan ke dalam larutan $2 \mathrm{mM} \mathrm{FeCl}_{2} \cdot 4 \mathrm{H}_{2} \mathrm{O}(0,05 \mathrm{~mL})$. Reaksi diinisiasi dengan penambahan $5 \mathrm{mM}$ ferrozine $(0,2 \mathrm{~mL})$. larutan dikocok dan dibiarkan pada suhu ruang selama 10 menit. Absorbansi larutan kemudian diukur pada panjang gelombang $562 \mathrm{~nm}$ terhadap blanko. Kontrol dibuat dengan cara yang sama namun tanpa ekstrak. EDTA dengan konsentrasi 100 ppm digunakan sebagai pembanding. Persentase penghambatan pembentukan kompleks ferrozine- $\mathrm{Fe}^{2+}$ dihitung dengan rumus:

Aktivitas mengkelat $(\%)=\left(1-\frac{\text { absorbansi sampel }}{\text { absorbansi kontrol }}\right) \times 100$

\section{Penentuan Reducing Power}

Penentuan reducing power sesuai yang dilakukan oleh Rajan dkk. (2011). Sebanyak $1 \mathrm{~mL}$ larutan ekstrak dengan konsentrasi $(20,40,60,80$, dan $100 \mathrm{mg} / \mathrm{L})$ ditambahkan dengan 2,5 mL buffer fosfat $(0,2 \mathrm{M}, \mathrm{pH} 6,6)$ dan $2,5 \mathrm{~mL}$ potasium ferisianida $\mathrm{K}_{3} \mathrm{Fe}(\mathrm{CN})_{6}(10 \mathrm{~g} / \mathrm{L})$, kemudian dikocok dan diinkubasi pada suhu $50{ }^{\circ} \mathrm{C}$ selama 20 menit. Selanjutnya ditambahkan 2,5 mL trichloroacetic acid $(100 \mathrm{~g} / \mathrm{L})$ kemudian disentrifugasi pada kecepatan $3000 \mathrm{rpm}$ selama 10 menit. Sebanyak 2,5 mL supernatan ditambahkan 2,5 mL akuades dan $0,5 \mathrm{~mL} \mathrm{FeCl}_{3}(1 \mathrm{~g} / \mathrm{L})$. absorbansi diukur pada panjang gelombang $700 \mathrm{~nm}$ menggunakan spektrofotometer UV-Vis.

Reducing power $(\%)=\left(\frac{\text { Absorbansi sampel }}{\text { Absorbansi blanko }}-1\right) \times 100$

\section{Rancangan Percobaan}

Penelitian ini menggunakan rancangan acak lengkap pola faktorial dengan perlakuan jenis dan konsentrasi pelarut. 
Seluruh perlakuan diulang sebanyak dua kali sehingga diperoleh 18 unit percobaan total. Data yang diperoleh dianalisis dengan sidik ragam, dan apabila terdapat pengaruh perlakuan terhadap parameter yang diamati, maka akan dilanjutkan dengan uji Duncan (Steel dan Torrie, 1993).

\section{HASIL DAN PEMBAHASAN}

\section{Total Fenolik}

Hasil analisis keragaman menunjukkan bahwa interaksi jenis dan konsentrasi pelarut berpengaruh sangat nyata terhadap total fenolik yang dihasilkan $(p<0,01)$. Nilai ratarata total fenolik yang dihasilkan dapat dilihat pada Gambar 1. Gambar 1 menunjukan bahwa kadar total fenolik tertinggi diperoleh dari jenis pelarut aseton 50\% yaitu sebesar 28,34 $\mathrm{mg} / \mathrm{g}$ bahan, sedangkan terendah diperoleh dari pelarut etanol $30 \%$ yaitu $10,72 \mathrm{mg} / \mathrm{g}$ bahan. Semakin tinggi konsentrasi etanol dan metanol maka total fenolik yang dihasilkan juga semakin tinggi, namun pada pelarut aseton konsentrasi pelarut yang optimum untuk mendapatkan total fenolik tertinggi dihasilkan dari aseton 50\%. Pada konsentrasi pelarut aseton $70 \%$, kadar total fenolik yang dihasilkan menurun. Hal ini menunjukan bahwa senyawa fenolik yang terdapat pada ekstrak daun alpukat bersifat polar. Perbedaan kadar total fenolik yang diperoleh dari penelitian ini dapat disebabkan oleh perbedaan polaritas pelarut yang digunakan serta perbedaan jenis senyawa fenolik dalam daun alpukat.

Menurut Stankovic dkk. (2012), material tanaman mengandung senyawa fenolik yang bervariasi dari yang sederhana hingga terpolimerisasi dalam jumlah yang berbeda. Polaritas pelarut berperan penting dalam peningkatan kelarutan senyawa fenolik. Prinsip umum dari ekstraksi menggunakan pelarut adalah like dissolves like, dimana pelarut hanya akan mengekstrak senyawa yang memiliki

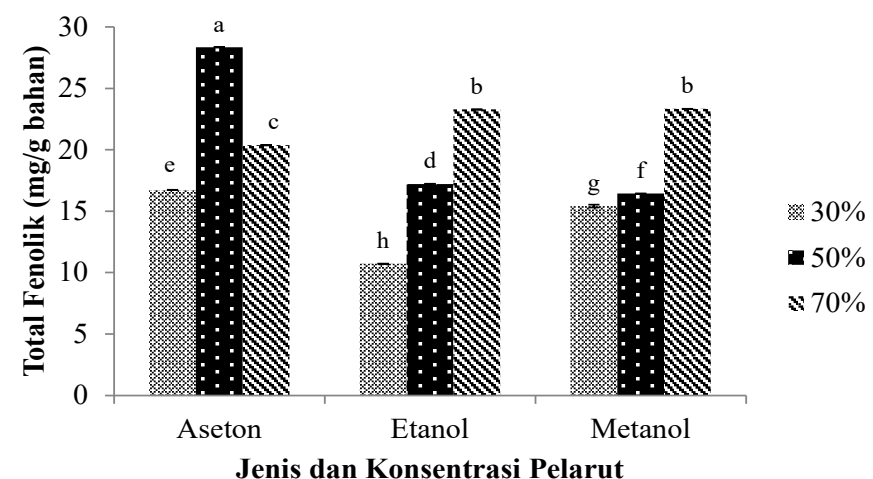

Gambar 1. Grafik hubungan antara jenis dan konsentrasi pelarut terhadap total fenolik ekstrak daun alpukat. Angka yang diikuti notasi huruf yang berbeda menunjukkan perbedaan yang nyata pada tingkat kepercayaan $95 \%(p<0,05)$ polaritas yang sama. Pelarut yang berbeda memiliki polaritas yang berbeda pula. Pelarut yang sama dengan konsentrasi yang berbeda juga memiliki polaritas yang berbeda. Polaritas aseton, etanol, dan metanol adalah 0,355, 0,654 dan 0,762 (Tan dkk., 2013). Polaritas pelarut-pelarut ini akan semakin meningkat seiring dengan penurunan konsentrasinya jika dilarutkan dalam air (Kumoro dkk., 2009). Hasil penelitian Tan dkk. (2013) juga melaporkan bahwa aseton merupakan pelarut yang baik digunakan untuk mengekstrak antioksidan polar dan mampu mengekstrak polifenol dari matrik protein yang disebabkan oleh kemampuannya untuk mendegradasi matrik polifenol-protein. Peningkatan konsentrasi aseton dari 60 hingga 100\% menghasilkan total fenolik yang semakin rendah. Sementara itu, etanol dan metanol lebih efektif untuk mengekstrak polifenol yang terkait dengan matrik berserat bersifat polar.

Menurut Fatiha dkk. (2012), jenis dan polaritas pelarut sangat mempengaruhi rendemen senyawa kimia yang dihasilkan. Lebih lanjut dilaporkan bahwa total fenolik pada Mentha spicata L. yang diekstrak dengan pelarut aseton 50\% lebih tinggi dibandingkan dengan aseton absolute (Fatiha dkk., 2012). Menurut Mokhtarpour dkk. (2014), total fenolik tertinggi pada produk samping Pistacia Vera L. diperoleh dengan pelarut aseton dibandingkan etanol, metanol, dan air. John dan Shahidi (2010) juga melaporkan bahwa total fenolik lebih tinggi diperoleh dari pelarut etanol dan metanol baik pada bagian kernel maupun kulit dari kacang Brazil.

Kadar total fenolik ekstrak daun alpukat lebih tinggi dibandingkan kadar total fenolik dari dua varietas buah pepaya (Hongkong dan Eksotika) yaitu 42,10 mg/100 g bahan dan $56,08 \mathrm{mg} / 100 \mathrm{~g}$ bahan yang juga diperoleh dari pelarut aseton 50\% (Addai dkk., 2013). Kadar total fenolik daun alpukat ini juga lebih tinggi dibandingkan kadar total fenolik teh hijau yaitu 72,70 mg/100 g bahan (Izzreen dan Fadzelly, 2013) dan total fenolik pada buah pare (Momordica charantia) yang diekstrak dengan pelarut metanol menggunakan ultrasonik yaitu 7,743 mg/g bahan (Budrat dan Shotipruk, 2008).

\section{Total Flavonoid}

Hasil analisis keragaman menunjukkan bahwa interaksi jenis dan konsentrasi pelarut berpengaruh sangat nyata terhadap total flavonoid yang dihasilkan $(p<0,01)$. Nilai rata-rata total flavonoid yang dihasilkan dapat dilihat pada Gambar 2.

Gambar 2 menunjukan bahwa kadar total flavonoid tertinggi diperoleh dari jenis pelarut etanol 70\% yaitu sebesar 93,97 mg/g bahan, sedangkan terendah diperoleh dari pelarut aseton $70 \%$ yaitu $21,45 \mathrm{mg} / \mathrm{g}$ bahan. Semakin tinggi konsentrasi pelarut etanol dan metanol maka kadar total flavonoid ekstrak daun alpukat yang diperoleh juga semakin 
tinggi, sebaliknya pada pelarut aseton dimana semakin tinggi konsentrasi aseton maka semakin rendah total flavonoidnya. Hal ini dapat disebabkan oleh kelarutan flavonoid yang lebih baik dalam pelarut alkohol seperti etanol dan metanol dibandingkan dengan aseton. Hal ini sesuai dengan yang dilaporkan oleh Addai dkk. (2013) bahwa kadar total flavonoid buah pepaya lebih tinggi diperoleh menggunakan pelarut etanol dan metanol dibandingkan aseton pada konsentrasi pelarut yang sama. Lebih lanjut dilaporkan oleh Addai dkk. (2013) bahwa kadar total flavonoid semakin rendah dengan semakin meningkatnya konsentrasi aseton dari 50\% sampai 100\%. Sementara itu, Fatiha dkk. (2012) melaporkan bahwa semakin tinggi konsentrasi metanol maka semakin tinggi pula total flavonoid yang dihasilkan pada ekstrak Mentha spicata L. Demikian juga pada pelarut etanol dimana, kadar total flavonoid yang lebih tinggi diperoleh dari etanol $75 \%$ dibandingkan dengan 50\%. Sementara itu, Zhang dkk. (2009), melaporkan bahwa kadar total flavonoid yang optimum pada daun Lotus (Nelumbo nuficera Gaertn) juga diperoleh dari etanol 70\% dibandingkan etanol $65 \%$ dan $75 \%$.

Kadar total flavonoid ekstrak daun alpukat lebih tinggi dari total flavonoid pada daun Lotus seperti yang dilaporkan oleh Zhang dkk. (2009) yaitu 71,5 mg/g dan lebih tinggi pula bila dibandingkan kadar total flavonoid dari dua varietas buah pepaya (Hongkong dan Eksotika) yaitu $0,33 \mathrm{mg} / \mathrm{g}$ bahan dan $0,31 \mathrm{mg} / \mathrm{g}$ bahan yang juga diperoleh dari pelarut etanol $70 \%$ (Addai dkk., 2013).

\section{Total Tanin}

Hasil analisis keragaman menunjukkan bahwa interaksi jenis dan konsentrasi pelarut berpengaruh sangat nyata terhadap total tanin yang dihasilkan $(p<0,01)$. Nilai rata-rata total tanin yang dihasilkan dapat dilihat pada Gambar 3.

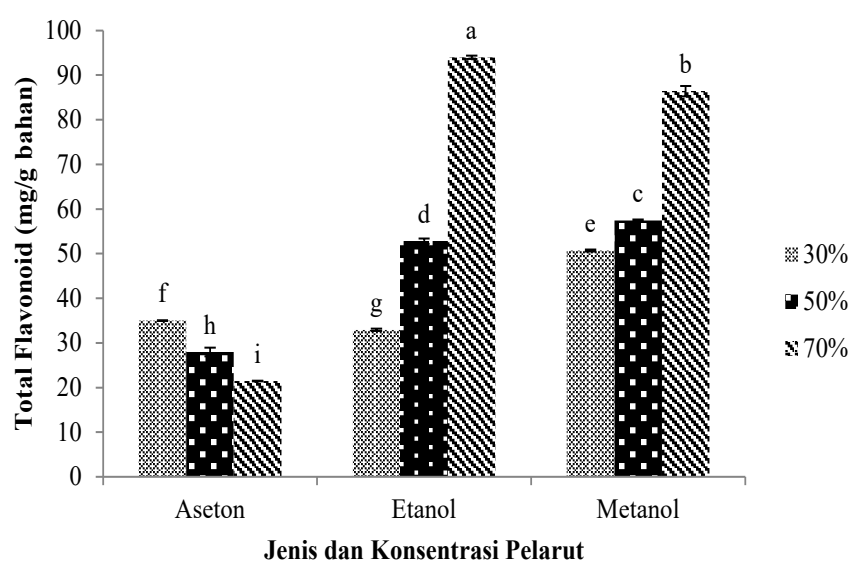

Gambar 2. Grafik hubungan antara jenis dan konsentrasi pelarut terhadap total flavonoid ekstrak daun alpukat. Angka yang diikuti notasi huruf yang berbeda menunjukkan perbedaan yang nyata pada tingkat kepercayaan $95 \%(p<0,05)$
Gambar 3 menunjukan bahwa kadar total tanin tertinggi diperoleh dari jenis pelarut aseton 50\% yaitu sebesar 12,31 $\mathrm{mg} / \mathrm{g}$ bahan, sedangkan terendah diperoleh dari pelarut etanol $30 \%$ yaitu $3,70 \mathrm{mg} / \mathrm{g}$ bahan. Hasil penelitian yang serupa juga dilaporkan oleh Chavan dan Amarowicz (2013) bahwa pelarut aseton lebih efektif digunakan untuk mengekstrak flavonoid dibandingkan metanol dan etanol pada Beach Pea (Lathyrus maritimus L.). Sementara itu, Mokhtarpour dkk. (2014) juga melaporkan bahwa total tanin tertinggi pada produk samping Pistacia Vera L. diperoleh dengan pelarut aseton dibandingkan etanol, metanol, dan air. Kadar total tanin pada ekstrak daun alpukat berada dalam kisaran kadar tanin pada teh hitam tanpa merek yang dipasarkan di Pakistan. Akhter dkk. (2013) melaporkan bahwa kadar total tanin pada beberapa jenis teh tanpa merek yang dipasarkan di Pakistan sekitar 0,4 sampai $68,3 \mathrm{mg} / \mathrm{g}$ bahan.

Semakin tinggi konsentrasi pelarut etanol dan metanol maka total tanin yang dihasilkan juga semakin tinggi, namun pada pelarut aseton konsentrasi pelarut yang optimum untuk mendapatkan total tanin tertinggi dihasilkan dari aseton 50\%. Hasil penelitian serupa juga dilaporkan oleh Downey dan Hanlin (2010) bahwa konsentrasi tanin pada kulit anggur semakin meningkat hingga konsentrasi aseton diantara 50$70 \%$. Kadar total tanin yang dihasilkan dengan pelarut aseton juga lebih tinggi dibandingkan etanol pada konsentrasi yang sama. Sementara itu, Yuliana dkk. (2014) melaporkan bahwa ekstraksi daun Swietenia mahagony menggunakan pelarut metanol dari $25-75 \%$ juga menghasilkan kadar tanin yang semakin meningkat.

Perbedaan kadar total tanin yang diperoleh dari penelitian ini dapat disebabkan oleh perbedaan polaritas pelarut yang digunakan. Menurut Fatiha dkk. (2012), jenis dan polaritas pelarut sangat mempengaruhi rendemen senyawa kimia yang

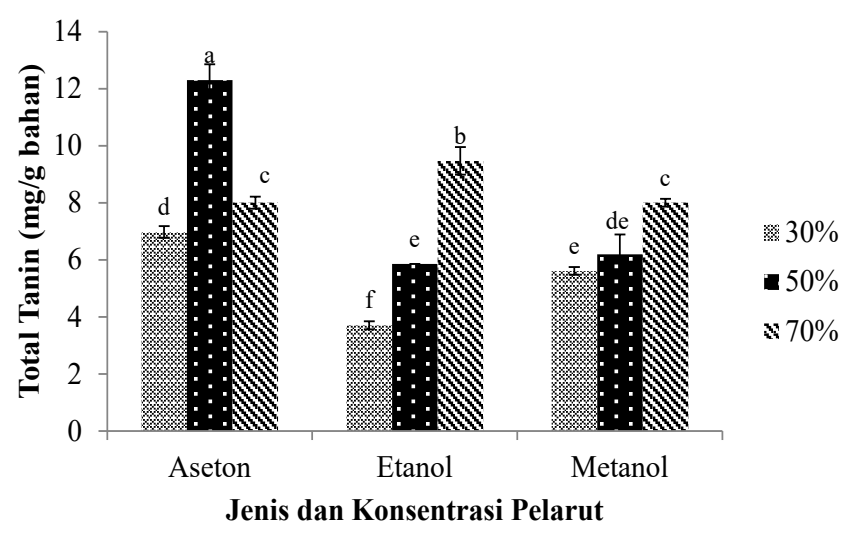

Gambar 3. Grafik hubungan antara jenis dan konsentrasi pelarut terhadap total tanin ekstrak daun alpukat. Angka yang diikuti notasi huruf yang berbeda menunjukkan perbedaan yang nyata pada tingkat kepercayaan 95\% $(\mathrm{p}<0,05)$ 
dihasilkan. Menurut Stankovic dkk. (2012), material tanaman mengandung senyawa fenolik yang bervariasi dari yang sederhana hingga terpolimerisasi seperti tanin dalam jumlah yang berbeda. Polaritas pelarut berperan penting dalam peningkatan kelarutan senyawa fenolik. Tingginya total tanin yang diperoleh pada ekstrak dengan pelarut aseton juga dapat disebabkan oleh kemampuannya untuk mendegradasi matrik polifenol-protein. Menurut Mailoa dkk. (2013), tanin merupakan senyawa polifenol dengan berat molekul yang tinggi dan dapat membentuk komplek dengan protein. Oleh karena itu, kadar tanin yang diperoleh dengan pelarut aseton lebih tinggi dibandingkan etanol dan metanol.

\section{Aktivitas Antioksidan (Penghambatan Radikal DPPH)}

Hasil analisis keragaman menunjukkan bahwa interaksi jenis dan konsentrasi pelarut berpengaruh nyata terhadap aktivitas antioksidan yang dihasilkan. Nilai rata-rata persentase aktivitas antioksidan yang dihasilkan dapat dilihat pada Gambar 4.

Gambar 4 menunjukan bahwa aktivitas antioksidan tertinggi diperoleh dari ekstrak daun alpukat dengan pelarut etanol $70 \%$ yaitu sebesar $90,80 \%$ yang berbeda tidak nyata dengan pelarut metanol $70 \%$ yaitu $90,65 \%$, sedangkan terendah diperoleh dari pelarut etanol $30 \%$ yaitu $87,83 \%$. Semakin tinggi konsentrasi pelarut maka aktivitas antioksidan yang dihasilkan juga semakin tinggi. Aktivitas antioksidan yang semakin tinggi dengan semakin meningkatnya konsentrasi etanol dan metanol dapat disebabkan oleh kadar total fenolik, total flavonoid dan total taninnya yang juga semakin meningkat dengan meningkatkan konsentrasi etanol dan metanol. Hal ini menunjukan adanya hubungan yang linier antara total fenolik, flavonoid, dan tanin yang diperoleh dari ekstrak daun alpukat dengan aktivitas antioksidan.

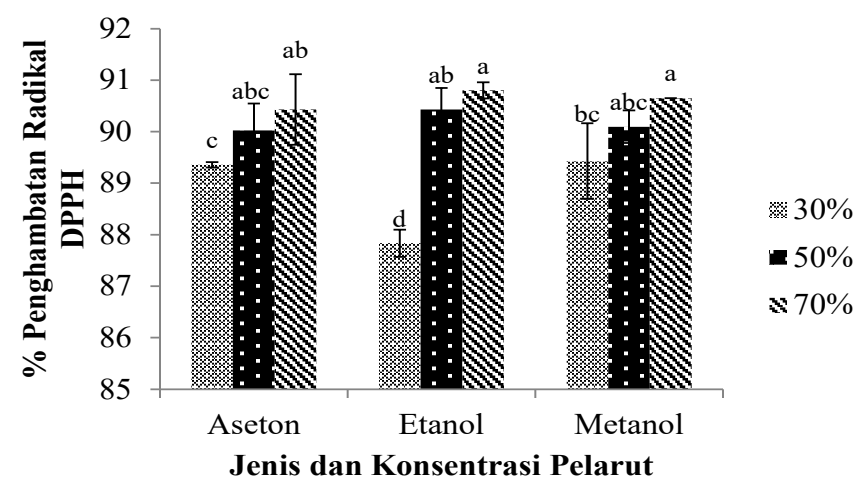

Gambar 4. Grafik hubungan antara jenis dan konsentrasi pelarut terhadap aktivitas antioksidan ekstrak daun alpukat. Angka yang diikuti notasi huruf yang berbeda menunjukkan perbedaan yang nyata pada tingkat kepercayaan $95 \%(p<0,05)$
Menurut Atanassova dkk. (2011), polifenol dan flavonoid merupakan senyawa yang sangat efektif berperan sebagai antioksidan. Sementara itu, aktivitas antioksidan yang diperoleh dari ekstrak pelarut aseton tidak menunjukkan adanya korelasi dengan kadar total fenolik, tanin, dan/atau flavonoid. Hal ini dapat disebabkan oleh komponen yang menyebabkan aktivitas antioksidan yang semakin tinggi dengan semakin meningkatnya konsentrasi aseton bukanlah senyawa fenolik, tanin, atau flavonoid melainkan senyawa yang belum teridentifikasi. Menurut Arukwe dkk. (2012), daun alpukat juga mengandung komponen bioaktif lainnya seperti saponin dan alkaloid. Alkaloid dan saponin ini merupakan senyawa yang dapat berperan sebagai antioksidan (Benhammou dkk., 2013). Menurut Kumar dkk. (2013), senyawa alkaloid dan saponin ini juga dapat larut dalam aseton.

\section{Nilai IC $_{50}$}

Berdasarkan hasil penelitian tahap I, dapat disimpulkan bahwa ekstrak terbaik diperoleh dari pelarut etanol $70 \%$. Dasar pertimbangannya adalah ekstrak yang diperoleh dengan pelarut etanol $70 \%$ memiliki aktivitas antioksidan tertinggi dan pelarut etanol bersifat food grade. Oleh karena itu, penentuan $\mathrm{IC}_{50}$ dilakukan pada ekstrak etanol $70 \%$. Nilai $\mathrm{IC}_{50}$ yang diperoleh dengan metode DPPH adalah 1860 $\mathrm{mg} / \mathrm{L}$. Hubungan antara konsentrasi ekstrak dengan aktivitas antioksidan dapat dilihat pada Gambar 5. Nilai $\mathrm{IC}_{50}$ dari ekstrak daun alpukat berada dalam kisaran nilai $\mathrm{IC}_{50}$ pada beberapa jenis madu seperti yang dilaporkan oleh Meda dkk. (2005) yaitu berskisar 16300-29130 mg/L. Nilai IC S0 $_{50}$ ekstrak daun alpukat lebih rendah dibandingkan nilai $\mathrm{IC}_{50}$ pada tujuh jenis macroalga yaitu $2,46-7,3 \mathrm{mg} / \mathrm{mL}$ seperti yang dilaporkan oleh Sarini dkk. (2014). Nilai IC $_{50}$ ekstrak daun alpukat juga lebih rendah dibandingkan beberapa jenis buah seperti yang dilaporkan oleh Yan dkk. (2006), diantaranya: pisang 13400 $\mathrm{mg} / \mathrm{L}$, buah naga $27500 \mathrm{mg} / \mathrm{L}$, belimbing $3800 \mathrm{mg} / \mathrm{L}$ dan jeruk $5400 \mathrm{mg} / \mathrm{L}$.

Sampel yang sama juga dilakukan analisis aktivitas pengkelatan ekstrak terhadap ion $\mathrm{Fe}^{2+}$. Hasil penelitian menunjukkan bahwa kemampuan ekstrak daun alpukat sebagai antioksidan juga diperoleh melalui pengkelatan $\mathrm{Fe}^{2+}$. Hal ini dapat dilihat dari nilai $\mathrm{IC}_{50}$ yang juga rendah yaitu $1180 \mathrm{mg} / \mathrm{L}$. Hubungan antara konsentrasi ekstrak dengan aktivitas antioksidan melalui pengkelatan ion $\mathrm{Fe}^{2+}$ dapat dilihat pada lebih rendah dibandingkan nilai $\mathrm{IC}_{50}$ dari ekstrak metanol daun Feijoa sellowiana dan Pterocarya fraxinifolia yaitu $2400 \mathrm{mg} / \mathrm{L}$ dan $1830 \mathrm{mg} / \mathrm{L}$ (Ebrahimzadeh dkk., 2008).

Menurut Atanassova dkk. (2011) senyawa flavonoid memiliki gugus hidroksil yang berperan sebagai penangkap radikal bebas dan mekanismenya dapat melalui proses 


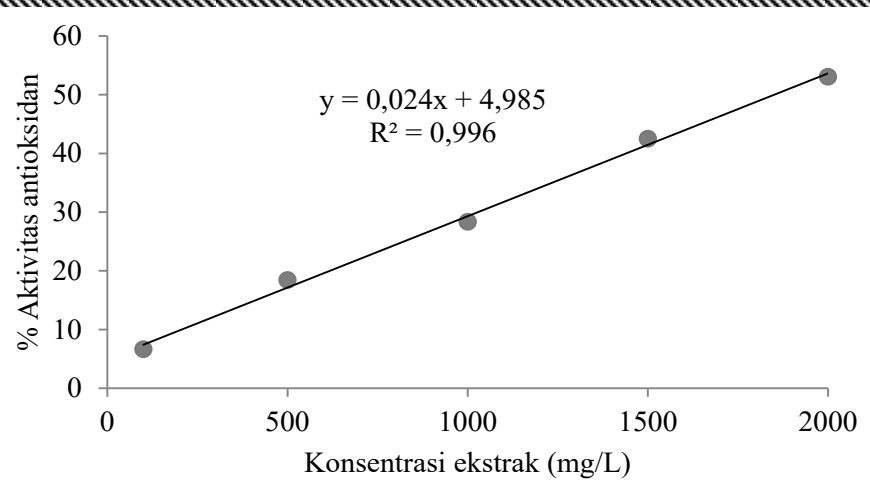

Gambar 5. Hubungan antara konsentrasi ekstrak dengan aktivitas antioksidan dengan metode DPPH

scavenging maupun pengkelatan. Suhartono dkk. (2012) melaporkan bahwa agen pengkelat sangat efektif berperan sebagai antioksidan sekunder karena mampu mereduksi potensial redok sehingga menstabilkan bentuk teroksidasi dari ion metal.

Kemampuan mereduksi dari suatu ekstrak merupakan indikator penting dari aktivitas antioksidan. Ekstrak daun alpukat juga menunjukan kemampuan reducing power yang sangat baik, yang dapat dilihat dari nilai $\mathrm{IC}_{50}$ yang rendah yaitu $85,24 \mathrm{mg} / \mathrm{L}$. Hubungan antara konsentrasi ekstrak dengan \% reducing power dapat dilihat pada Gambar 7. Nilai $\mathrm{IC}_{50}$ ekstrak daun alpukat dilihat dari nilai reducing power ini lebih rendah dari ekstrak Eupatoriurn odoraturn yaitu 3,16 $\mathrm{mg} / \mathrm{ml}$ (Deng dkk., 2015). Pada pengujian reducing power, adanya antioksidan dalam sampel mengakibatkan reduksi $\mathrm{Fe}^{3+}$ menjadi $\mathrm{Fe}^{2+}$ dengan mendonorkan elektron (Rosalind dkk., 2013). Menurut Soni and Sosa (2013), senyawa yang memiliki kemampuan mereduksi menunjukan bahwa senyawa tersebut dapat mendonorkan elektron dan mereduksi

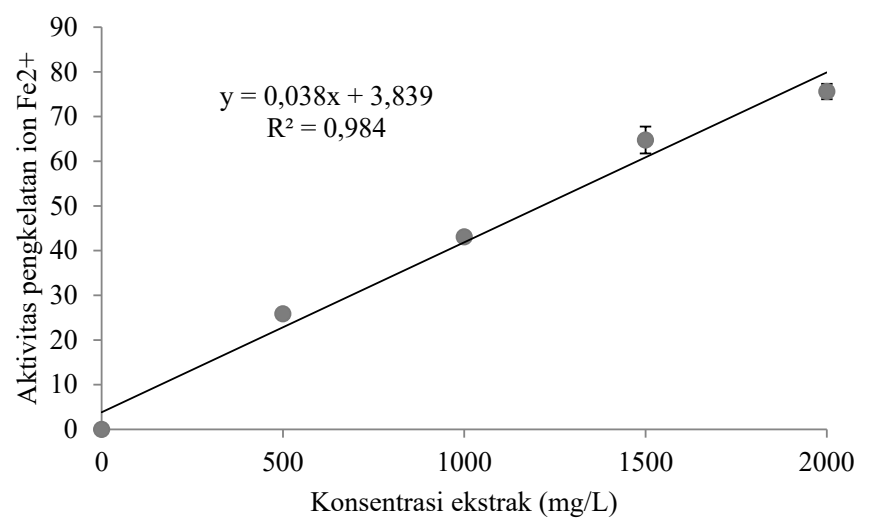

Gambar 6. Hubungan antara konsentrasi ekstrak dengan aktivitas pengkelatan ion $\mathrm{Fe}^{2+}$

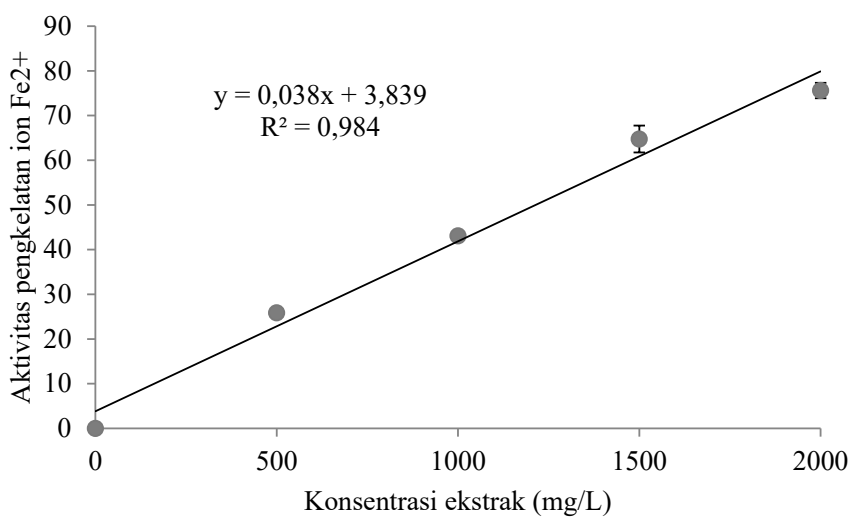

Gambar 7. Hubungan antara konsentrasi ekstrak dengan \% Reducing power

produk intermediate hasil oksidasi pada proses peroksidasi lipida sehingga dapat berperan sebagai antioksidan primer dan sekunder.

Menurut Plaza dkk. (2014) melaporkan bahwa aktivitas reducing power dapat diakibatkan oleh keberadaan polifenol yang dapat berperan sama seperti redukton dengan mendonorkan elektron dan bereaksi dengan radikal bebas sehingga menghasilkan produk yang lebih stabil dan menghambat reaksi berantai radikal bebas.

\section{KESIMPULAN}

Berdasarkan hasil penelitian dapat disimpulkan bahwa interaksi jenis dan konsentrasi pelarut berpengaruh nyata terhadap total fenolik, total flavonoid, total tanin, dan aktivitas antioksidan ekstrak daun alpukat. Pelarut yang tepat digunakan untuk memperoleh ekstrak daun alpukat dengan aktivitas antoksidan yang tertinggi adalah etanol $70 \%$ dengan kadar total fenolik, flavonoid, tanin dan aktivitas antioksidan masing-masing adalah 23,28 mg/g bahan, 93,97 mg/g bahan, $9,47 \mathrm{mg} / \mathrm{g}$ bahan dan $90,80 \%$. Sementara itu, nilai $\mathrm{IC}_{50}$ baik yang diukur dengan metode $\mathrm{DPPH}$, pengkelatan $\mathrm{Fe}^{2+}$ dan reducing power adalah $1870 \mathrm{mg} / \mathrm{L}, 1180 \mathrm{mg} / \mathrm{L}$, dan 85,24 $\mathrm{mg} / \mathrm{L}$.

\section{UCAPAN TERIMA KASIH}

Ucapan terimakasih disampaikan kepada Rektor Universitas Udayana melalui Ketua LPPM atas dana penelitian yang diberikan dalam bentuk Hibah Penelitian Dosen Muda dengan Surat Perjanjian Penugasan Pelaksanaan Penelitian Nomor: 391-28/UN14.2/PNL.01.03.00/2015, tanggal 1 Juni 2015. 


\section{DAFTAR PUSTAKA}

Addai, Z.R., Abdullah, A. dan Mutalib, S.A. (2013). Effect of extraction solvents on the phenolic content and antioxidant properties of two papaya cultivars. Journal of Medicinal Plants Research 7: 3354-3359.

Atanassova, M., Georgieva, S. dan Ivancheva, K. (2011). Total phenolic and total flavonoid contents, antioxidant capacity and biological contaminants in medicinal herbs. Journal of the University of Chemical Technology and Metallurgy 6: 81-88.

Arukwe, U., Amadi, B.A., Duru, M.K.C., Agomuo, E.N., Adindu, E.A., Odika, P.C., Lele, K.C., Egejuru, L. dan Anudike, J. (2012). Chemical composition of persea americana leaf, fruit and seed. International Journal of Research and Reviews in Applied Sciences 11: 346-349.

Akhter, S., Masood, S., Jadoon, H.S., Ahmad, I., Fen, Z. dan Salariya, A. M. (2013). Evaluation of quality of different non-branded samples of black tea. Pakistan Journal Food Science 23: 66-70.

Asaolu, M.F., Asaolu, S.S. dan Adanlawo, I.G. (2010). Evaluation of phytochemicals and antioxidants of four botanicals with antihypertensive properties. International Journal of Pharma and Bio Sciences 6: 1-7.

Benhammou, N., Ghambaza, N., Benabdelkader, S., Bekkara, F.A. dan Panovska, T.K. (2013). Phytochemicals and antioxidant properties of extracts from the root and stems of Anabasis Articulate. International Food Research Journal 20: 2057-2063.

Bimakr, M., Rahman, R.A., Taip, S.F., Adzahan, N.M., Sarker, I.Z. dan Ganjloo, A. (2013). Ultrasound-assisted extraction of valuable compounds from winter melon (Benincasa hispida) seeds. International Food Research Journal 20: 331-338.

Budrat, P. dan Shotipruk, A. (2008). Extraction of phenolic compounds from fruits of bitter melon (Momordica charantia) with subcritical water extraction and antioxidant activities of these extracts. Chiang Mai Journal Science 35: 123-130.

Chavan, U.D. dan Amarowicz, R. (2013). Effect of various solvent systems on extraction of phenolics, tannins and sugars from beach pea (Lathyrus maritimus L.). International Food Research Journal 20: 1139-1144.

Chew, K.K., Ng, S.Y., Thoo, Y.Y., Khoo, M.Z., Wan Aida, W.M. dan Ho, C.W. (2011). Effect of ethanol concentration, extraction time and extraction temperature on the recovery of phenolic compounds and antioxidant capacity of Centella asiatica extracts. International Food Research Journal 18: 571-578.

Deng, Q., Zhang, X., Liu, F., Huang, L., Yang, X. dan Xu, J. (2015). Determination of the total phenolic and flavonoid contents in Eupatoriurn odoraturn, as well as their antioxidant activities. Journal of Chemical and Pharmaceutical Research 7: 986-993.

Downey, M.O. dan Hanlin, R.L. (2010). Comparison of ethanol and acetone mixtures for extraction of condensed tannin from grape skin. South African Journal Enology and Viticulture 31:154-159.

Ebrahimzadeh, M.A., Pourmorad, F. dan Bekhradnia, A.R. (2008). Iron chelating activity, phenol and flavonoid content of some medicinal plants from Iran. African Journal of Biotechnology 7: 3188-3192.

Fatiha, B., Khodir, M., Farid, D., Tiziri, R., Karima, B., Sonia, O. dan Mohamed, C. (2012). Optimisation of solvent extraction of antioxidants (phenolic compounds) from Algerian mint (Mentha spicata L.). Pharmacognosy Communications 2: 72-86.

Garcia, C.A., Gavino, G., Mosqueda, M.B., Hevia, P. dan Gavino, V.C. (2007). Correlation of tocopherol, tokotrienol, $\gamma$-oryzanol and total polyphenol content in rice bran with different antioxidant capacity assays. Food Chemistry 102: 1228-1232.

Hismath, I., Wan Aida, W.M. dan Ho, C. W. (2011). Optimization of extraction conditions for phenolic compounds from neem (Azadirachta indica) leaves. International Food Research Journal 18: 931-939.

Ince, A. E., Şahin, S. dan Şümnü, S.G. (2013). Extraction of phenolic compounds from melissa using microwave and ultrasound. Turkish Journal of Agriculture and Forestry 37: 69-75.

Izzreen, N.Q. dan Fadzelly, M. (2013). Phytochemicals and antioxidant properties of different parts of Camellia sinensis leaves from sabah tea plantation in Sabah, Malaysia. International Food Research Journal 20: 307-312.

John, J. A. dan Shahidi, F. (2010). Phenolic compounds and antioxidant activity of Brazil nut (Bertholletia excelsa). Journal of Functional Foods 2: 196-209.

Khan, R.A., Khan, M.R., Sahreen, S. dan Ahmed, M. (2012). Evaluation of phenolic contents and antioxidant activity of various solvent extracts of Sonchus asper (L.) Hill. Chemistry Central Journal 6: 1-7.

Kolawole, O.T., Kolawole, S.O., Ayankunle, A.A. dan Olaniran, I. O. (2012). Methanol leaf extract of Persea americana protects rats against cholesterol-induced 
hyperlipidemia. British Journal of Medicine and Medical Research 2: 235-242.

Kumar, C., Kumar, R.,dan Nehar, S. (2013). Phytochemical properties, total antioxidant status of acetone and methanol extract of Terminalia arjuna Roxb. bark and its hypoglycemic effect on Type-II diabetic albino rats. Journal of Pharmacognosy and Phytochemistry 2: 199208.

Kumoro, A.C., Hasana, M. dan Singha, H. (2009). Effects of solvent properties on the Soxhlet extraction of diterpenoid lactones from Andrographis paniculata leaves. Science Asia 35: 306-309.

Mailoa, M.C., Mahendradatta, M., Laga A. dan Djide, N. (2013). Tannin extract of guava leaves (Psidium guajava L) variation with concentration organic solvents. International Journal of Scientific and Technology Research 2: 106-110.

Mardiyaningsih, A. dan Ismiyati, N. (2014). Aktivitas sitotoksik ekstrak etanolik daun alpukat (Persea americana mill.) pada sel kanker leher rahim hela. Traditional Medical Journal 19: 24-28.

Marrero-Faz, E., Sánchez-Calero, J., Young, L. dan Harvey, A. (2014). Inhibitory effect of Persea Americana Mill leaf aqueous extract and its fractions on PTP1B as therapeutic target for type 2 diabetes. Boletín Latinoamericano y del Caribe de Plantas Medicinales y Aromáticas 13: 144-151.

Meda, A., Lamien, C.E, Romito, M., Millogo, J. dan Nacoulma., O.G. (2005). Determination of the total phenolic, flavonoid and proline contents in Burkina Fasan honey, as well as their radical scavenging activity. Food Chemistry 91: 571-577.

Mokhtarpour, A., Naserian, A.A., Valizadeh, R., Mesgaran, M.D. dan Pourmollae, F. (2014). Extraction of phenolic compounds and tannins from Pistachio by-products. Annual Research and Review in Biology 4: 1330-1338.

Ogundare, A.O. dan Oladejo, B.O. (2014). Antibacterial activities of the leaf and bark extract of Persea americana. American Journal of Ethnomedicine 1: 064-071.

Owolabi, M.A., Coker, H.A.B. dan Jaja, S.I. (2010). Bioactivity of the phytoconstituents of the leaves of Persea americana. Journal of Medical Plants Research 4: 1130-1135.

Plaza, C.M., de Torres, L.E.D., Lücking, R.K., Vizcaya, M. dan Medina, G.E. (2014). Antioxidant activity, total phenols and flavonoids of lichens from Venezuelan
Andes. Journal of Pharmacy and Pharmacognosy Research 2: 138-147.

Rajan, S., Mahalakshmi, S., Deepa, V., Sathya, K., Shajitha, S. dan Thirunalasundari, T. (2011). Antioxidant potentials of punica granatum fruit rind extracts. International Journal of Pharmacy and Pharmaceutical Sciences 3: 82-88.

Rosalind, T.H., Dutta, B.K. dan Paul, S.B. (2013). Evaluation of in vitro antioxidant activity, estimation of total phenolic and flavonoid content of leaf extract of Eurya japonica Thunb. Asian Journal of Pharmacy Clinical Research 6: 152-155.

Sarini, A.W., Aishah, H.N. dan Zaini, N.M. (2014). Determination of antioxidant activity for seven types of macroalgae. $5^{\text {th }}$ International Conference on Food Engineering and Biotechnology 65: 51-56.

Singh, R., Verma, P.K. dan Singh, G. (2012). Total phenolic, flavonoids and tannin contents in different extracts of Artemisia absinthium. Intercultural Ethnopharmacol 1: 101-104.

Soni, A. dan Sosa, S. (2013). Phytochemical analysis and free radical scavenging potential of herbal and medicinal plant extracts. Journal of Pharmacognosy and Phytochemistry 2: 22-29.

Stankovic, M.S. Niciforovic, N., Mihailovic, V., Topuzovic, M. dan Solujic, S. (2012). Antioxidant activity, total phenolic content and flavonoid concentrations of different plant parts of Teucrium polium L. subsp. polium. Acta Societatis Botanicorum Poloniae 81: 117 122.

Steel, R.G.D. dan Torrie, J.H. (1993). Prinsip dan Prosedur Statistik Suatu Pendekatan Biometric. Penerjemah Bambang Sumantri. PT. Gramedia Pustaka Utama, Jakarta.

Suhartono, E., Viani, E., Rahmadhan, M.A., Gultom, I.S., Rakhman, M.F. dan Indrawardhana, D. (2012). Screening of medicinal plant for total flavonoid and antioxidant activity in South Kalimantan of Indonesian. International Journal of Chemical Engineering and Applications 3: 297-299.

Tahla, J., Priyanka, M. dan Akanksha, A. (2011). Hypertension and herbal plants. International Research Journal of Pharmacy 2: 26-30.

Tan, M.C., Tan, C.P. dan Ho, C.W. (2013). Effects of extraction solvent system, time and temperature on total phenolic content of henna (Lawsonia inermis) stems. International Food Research Journal 20: 3117-3123. 
Yan, L.Y, Teng, L.T. dan Jhi, T.J. (2006). Antioxidant properties of guava fruit: comparison with some local fruits. Sunway Academic Journal 3: 9-20.

Yuliana, P., Laconi, E.B., Wina, E. dan Jayanegara, A. (2014). Extraction of tannins and saponins from plant sources and their effects on in vitro methanogenesis and rumen fermentation. Journal of Indonesian Tropical Animal Agriculture 39: 91-97.
Zhang, L., Shan, Y., Tang, K. dan Putheti, R. (2009). Ultrasound-assisted extraction flavonoids from Lotus (Nelumbo nuficera Gaertn) leaf and evaluation of its anti-fatigue activity. International Physical Science 4: 418-422. 